\title{
Explication of the axiological component of the "despair" emotion (in English, Russian, Ukrainian and German languages)
}

\author{
Y. Petrenko \\ O. O. Potebnia Institute of Linguistics, National Academy of Sciences of Ukraine, Kyiv, Ukraine \\ Kherson National Technical University, Kherson, Ukraine \\ Corresponding author. E-mail: Ievgeniiapetrenko1991@gmail.com
}

Paper received 15.05.20; Accepted for publication 03.06.20.

\section{https://doi.org/10.31174/SEND-HS2020-230VIII38-11}

\begin{abstract}
The axiological component depends on the context and is influenced by the speaker, the addressee of the speech and the communicative goal. There are different categories of evaluation and types of value, however, emotions deal with hedonic and moral ones. This article contains actual material gathered from the language corpus in English, Russian, Ukrainian and German, in order to illustrate that the "despair" emotion is the negative one and determine specific means of its objectification and explication of the axiological component.
\end{abstract}

Keywords: axiological component, attitudinal meaning, evaluation, emotion, conceptualization, explication

Introduction. People are not always aware of the presence of different emotions in their mind and their influence on their behavior. However, emotions play a key role in mental health, human communication and societal interaction. For this reason they became an important study object in different fields of science, including linguistics. The axiological component is one of the main meaning elements in semantics of emotive vocabulary. Negative emotions still remain less studied than positive emotions. Among negative emotions only fear and anger have been properly researched. Words and phrases that designate emotion of despair, however, did not receive proper attention of linguists - especially in Ukrainian and German languages. My research is particularly focused on the "despair" emotion and this paper deals with its axiological component.

Survey of publications. Since emotions in language have become a relevant line of research in modern linguistics, there is a wide range of research devoted to this topic from leading experts in this field, namely Zoltán Kövecses, George Lakoff, Mark Johnson, Robert Plutchik, Raymond Gibbs, Paul Ekman, Carroll E. Izard, Keith Oatley, Yurii Apresyan, Walentina Apresian, Svitlana Zhabotynska, Victor Shakhovsky and others. My research is based on their findings. However, many issues related to the emotions and the linguistic means of their expression have not yet been fully investigated. The most researched are six basic emotions: happiness, surprise (positive) and fear, anger, disgust (negative). In some cases, it is difficult to define whether emotion is positive or negative (for example "compassion"), which caused an interest to its analysis in modern linguistics [3;11].Studies of emotions form prospective of cultural semantics have revealed semantic differences between emotion words given in the dictionaries as translation equivalents, as well as quantitative differences across languages.

Objective, material, methodology. The paper's objective is to analyze the explication of the axiological component of the "despair" emotion, based on language corpus material. From a methodological point of view, I will employ the corpus analysis method, which allows for examination of a rich source of data in English, German, Ukrainian and Russian, and distributive analysis. I will also adhere to the contrastive analysis method.

Results and discussion. Attitudinal meaning has interested philosophers, logicians and linguists for centuries.
They've produced a number of important hypotheses and concepts that form a basis for current research. Aristotle already elaborated a linguistic approach to distinguishing between attitudinal meanings. Similar approach was developed by John Locke in his hedonic concept of good and bad, where good interacts with pleasure and bad interacts with suffering. Comparison of these two polar states creates its gradation, namely, states of varying intensity [9, p.244].

The axiological component is an excellent representative of pragmatic meaning that is one acquiring in the context. Non-descriptive words (including emotive vocabulary) depend heavily on the broad context, which includes external factors. Attitudinal meaning is heavily reliant on the speaker, as it expresses his/her personal opinion and tastes, which are different for each person. It's necessary to consider that evaluative predicates are addressed to the addressee of the speech, who also becomes the factor that influences on the axiological component. Some scientists consider the influence on the addressee to be the main function of evaluation [4, p.16]. Therefore, the interpretation of the attitudinal meaning includes three factors: the speaker, the addressee and the communicative goal of the particular speech act. Considering that the attitudinal meaning depends significantly on the context, it is very hard to define the pragmatic meaning type, and, consequently, the problem of interpretation arises.

Georg Henrik von Wright developed the classification of categories of evaluation on the part of logic. It is based on the use of the adjective "good" and its antonyms. There are the following categories: 1) instrumental; 2) technical; 3) utilitarian; 4) beneficial; 5) medical and 6) hedonic [5, p.18-20]. Georg Henrik von Wright combines instrumental and technical evaluations as they are based on a functional principle. Utilitarian and beneficial evaluations are both based on a benefit principle for fulfillment of the specific task. Medical evaluation concerns the human body, both internal organs and mental abilities and state. Hedonic evaluation applies to the states only, regardless of the category of objects they were caused by.

Nina Arutyunova reconsiders the Georg Henrik von Wright's classification on the part of linguistics. She divides the attitudinal meaning into two groups: general and private. The first one is realized by using the adjectives "good" and "bad", their synonyms, stylistic and expressive shades. This evaluation is an axiological outcome, namely 
reflects a set of features. The second one includes evaluation of certain aspects of the objects from the certain viewpoint, and it is divided into the following categories: 1) sensory and taste (or hedonic); 2) psychological (including intellectual and emotional); 3) aesthetical (synthesis of sensory and taste together with psychological); 4) ethical; 5) utilitarian; 6) standard-compliant and 7) teleological. These categories form three sub-groups. The first subgroup includes the first two categories. Therefore it deals with the characteristics of the subject rather than the object. The second sub-group includes aesthetical and ethical evaluations associated with a sense of beauty and morality. The other categories form the third sub-group of rational evaluation relating to activities and daily experience of a human [6, p. 75-77].

Agnieszka Mikołajczuk distinguishes two types of values in relation to linguistic objectification of emotions: hedonic or sensory (pleasure / discomfort) and moral or ethical (good / evil, approval / condemnation) [3, p.121]. The vectors of hedonic and ethical evaluations usually match. Elena Wolf considers evaluation as positive or negative, explicit or implicit attitude of the experiencer to the objects of reality fixed in the semantics of a linguistic unit [7, p.18]. With regard to the above mentioned, positive and negative evaluations contain different axiologically relevant features, which lead to the need for their explication, especially for general evaluation. Evaluation is essential to conceptualization of the world around us. Emotions are varied assessments of the situation, and therefore they take part in the conceptualization of the world, although they may also receive axiological characteristics [11, p.32].

I apt to define the "despair" emotion as a negative one. This emotion is uncomfortable and painful experience of the experiencer from the perspective of hedonic values, as evidenced by the contextual combination of names of "despair" emotion in texts of various genres gathered from the national language corpus by the blind search method. Moral evaluation refers to a human behavior and his/her relationships with others. The "despair" is principally negative emotion in the indicated languages, as evidenced by the cooccurrence range of its names with adjectives that have negative semantics: English. Maria was momentarily gripped by an odd, angry despair in response to his denial that he was having an affair with Cavell.; $\langle\ldots\rangle$, she looked round for her other shoe and could only watch in helpless despair as she saw it slowly sink.; As she clenched her hands on the rail until they hurt, she fought to hate him, to make herself angry, not to give in to the terrible despair that kept threatening to overwhelm her[1].; Russian. Эmo бессильное отчаяние, в порыве встать с колен и снова падающее!; <..> я все равно не забуду, что самое страшное отчаяние в моей жизни было, когда плохо повешенный мною на гвоздик тазик в уборной рухнул и расколол смывной бачок в час ночи [10]. Ukrainian. I вже обурювався й закипав гнівом, протестом, мстивою злістю, гірким полином прокляття й безвихідного розпачу <...>; Я пережсиав страшний розпач.; Коваль слухняно позбирав старі підкови, серед яких були такі тонкі, як листя, а в душі чув жсахливий розnay[8].; German. Jetzt brauchte er nicht mehr sein Gefühl zu überhitzen, um sich selbst zu täuschen in dem Gedanken ihrer Unschuld an seinem Fall, um Renate zu täuschen über seine schwere Verzweiflung.; Gott nur fürchten, und auf ihn nicht mehr hoffen, ist die schreckliche Verzweiflung der Verworfenen [2].

Negative evaluation of the "despair" emotion may be intensified by accompanying negative emotions or combining with them as synonyms in the context: English. Amidst the wails of terror, the last breaths of despair and defeat,..; Her eyes fixed widely on his, despair and unhappiness in their depths, she asked miserably <...>; That devil, born of isolation, he had seen so often destroy young men through exhaustion, frustration and despair.; Fear and despair gripped him.; It had held too many of her hopes, too much optimism, to suit her present anger and despair [1].; Russian. Oт cmpaxa и отчаяния она громко вскрикивает.; И вскоре ужас и отчаяние охватили меня, $и$ показалось мне, <...>; Но знаете, я ожидал от матери большего горя и отчаяния, ведь я видел её реакцию на арест отия [10].; Ukrainian. Коли Гасай повернувся i доповів султанші, що все зроблено, як вона веліла, не побачив на ї̈ обличчі ніяких слідів горя і розпачу, щчо були в душі Роксолани.; Колона посунула берегом річки, i Андрій насилу стримався, щяоб не крикнути од болю $\boldsymbol{i}$ розпачу за своїх майбутніх товаришів.; В ньому клекотіла злість, обурення, їх подвоїло чи й потроїло почуття радості, щзо син живий $і$ вернувся, йому несвідомо хотілося доплатити за свій страх і розпач [8].; German. Verzweiflung und Hoffnungslosigkeit breiten sich schnell aus. Ihre Aufregung steigert sich zu Panik und Verzweiflung, und mündet letztlich in Resignation.; Durch die Häufung der Terroranschläge überwiegen bei ihm Wut, Verzweiflung und Trauer.; Schmerz und Verzweiflung waren schon immer seine größten Antreiber [2].

The negative nature of the "despair" emotion is intensified by opposition to positive emotions in the context: English. Happiness and despair and hope and fear and $<. . .>$.; It was joy and despair for former West Ham stars Tony Cottee and Mark Ward as Everton scored a shock 3-2 win at Blackburn last night.; It was a consciousness of joy and pain, of celebration and concern, of thinking and feeling, of hope and despair [1].; Russian. Надежнда u отчаяние сменяли друг друга.; Это история любви и отчаяния... в течение тридияати лет Мария Хосее Карраско страдала рассеянным склерозом.; Мы будем видеть с тобой два разных пейзажа, как по-разному были осуждень произносить звуки, готовить завтрак и ужин, выражать радость и отчаяние [10].; Ukrainian. Красно вам дякую, - сказав Юрій Юрійович, не пам'ятаючи себе одночасно від щиастя $\boldsymbol{i}$ розпачу, $<$ <..>; Полонені німиі зводили цей квартал з любов'ю $\boldsymbol{i}$ розпачем.; Я передзвоню іншим разом... Ще тиждень між надією і розпачем!'88]; German. Das Ergebnis ist eine erschütternde Reportage zwischen Hoffnung und Verzweiflung.; Am Turnerchränzli in Büsingen drehte sich alles um Liebe, Verzweiflung und neues Glück.; Diese Würfel machen Spaß und bringen einen manchmal auch zur Verzweiflung [2].

The "despair" emotion is conceptualized through images of aggressive force, water element and fire (temperature characteristics), which indicates different intensity, duration of emotion and its destructive influence on the experiencer. "Warm" feelings represent positive hedonic and moral evaluation [11, p. 39], and therefore the "despair" emotion, which expresses negative evaluation, is usually characterized as "cold": English. Now cold despair, 
succeeding in her stead.; Her father had been in bleak despair, and Caroline had been dispatched to a childless relative for the duration of the trauma [1].; Russian. Fpaсов прохаживается вдоль вагонов, такой красивый, строгий и важный в своём холодном отчаянии, что теперь никто не принял бы его за вора [10].; Но я мужчина, и меня охватывает ледяное отчаяние при мыслли, что я никогда уже не буду бродить по краю пропасти[10].; Ukrainian. Холодний розпач стискає серие.; Голодний і холодний розпач знову огорнув його душу, $i$, щуоб не думати про сумне, він почав <...> [8].; German. Kalte Verzweiflung bohrte sich in seinen Unterleib. Ich durchdrang die Büsche am Ausgang der Schlucht - und blieb wie angewurzelt stehen, während eisige Verzweiflung mein Herz verkrampfte [2].

The experiencer shows no wish to extend the duration of the "despair" emotion; by contrast, he/she aims to get rid of it as soon as possible, associating this emotion with illness or enemy: English. The idea that the antidote to despair is action is one of the most powerful I ever learned.; Fourteen months ago we were told $<\ldots>$ that it would be difficult, if not impossible, to recover from the despair and the destruction of the era.; It might also be that the urge to rescue philosophical critique from despair reproduces the very condition it abhors [1].; Russian. Чтобы совсем не погибнуть от отчаяния и одиночества, он поступил в аспирантуру в близлежащий университет.; Приступы отчаяния тянулись до первой спасительной мысли [10].; Как вы боретесь с отчаянием? [10]; Ukrainian. Коли перший напад розпачу пройшов, хлопчик помітив, щзо стоїть по кісточки у воді <...>; Дітлахам розповіли як поводитись у надзвичайних ситуаціях, як побороти розпач $i$ тривогу та не піддаватись паніці у випадку пожежі.; Найкращі ліки від розпачу служіння іншим [8].; German. Texte ihrerseits düstere Themen wie Tod, Leid und Verzweiflung behandeln können-so besonders im Fall der später ausgesonderten $<\ldots>$; Arbeit ist das beste Mittel gegen Verzweiflung.; Der Therapeut half mir, meine Verzweiflung zu überwinden [2].

The "despair" emotion is so destructive that the experiencer tries to stop its influence by any means, thus it leads to committing suicide. This claim is illustrated with the following examples: English. Usually though, suicide is an act of complete despair, performed by an individual who feels there is no other option, <...>; He is an effective communicator who knows the industry's problems and is concerned that too few know about the level of despair which can make a farmer twice as likely to commit suicide as the average man.; More Americans could lose their lives to deaths of despair, deaths due to drug, alcohol, and suicide, if we do not do something immediately [1].; Russian. Он в отчаянии наложил на себя руки, а его тело затоптали те, кого он пытался спасти от неволи.; От отчаяния каждый день мы пытались бы себя убить.; Увидав, что урожай в том году будет лучше, чем он предполагал, он повесился с отчаяния [10].; Ukrainian. У захваті від власних успіхів, Всеволод Ольгович наступного року навіть вдало втрутився в усобищю в Польщі, але щуе через рік зазнав поразки від Володимирка й, можливо, від розпачу помер.; Навпаки, він мало не втратив держави після однієї поразки від росіян, після чого в розпачі хотів накласти на себе руки, <...> [8]. German. Lebte er noch, dieser Anblik würde ihn zur Verzweiflung treiben; ja, er würde seinen guten Engel von seiner Seite wegfluchen, und in Verzweiflung sterben.; Selbst wenn die Dunkelheit keine Einzelheiten erkennen ließ, so war ihm doch sofort klar, wer da soeben voller Verzweiflung sein Leben wegwerfen wollte.; Sie täuscht sich, und ist im Begriff, im Übermaße der Verzweiflung Hand an sich selbst zu legen [2].

The "despair" emotion explicates also with bodily reactions. The experiencer bears physical discomfort that produces some external manifestation. It is usually manifested in:

- eyes: English. I could see hunger, exhaustion and despair in their eyes.; Homeless woman is depressed, looking at the camera with eyes full of despair and despond [1].; Russian. Внезапно, все ее тело взорвала дикая боль, в глазах отразилось неверие и шок, они наполнились отчаянием.; Ее миндалевидные карие глаза светились отчаянием и яростью [10].; Ukrainian. В ӥхніх очах нема тієі печаті розпачу $i$ безнадійності, яка є у місцевих людей.; < .. > погляд, щчо палає в розпачі й ніколи не згасне [8].; German. Ich werde mich noch lange an die Verzweiflung in den Augen dieser Einwanderer erinnern.; Aus seinen Augen sprach die Verzweiflung [2].

voice and sounds: English. Evelyn's voice was so filled with despair that Kate felt rage again.; The despair in his voice tore at her heart.; Those who lose heart and cry out in despair <...>[1]; Russian. Om его лежавшего на траве тела донесся слабый, полный отчаяния стон.; Его взгляд потускнел, в голосе звенело отчаяние.; Слезы начнут течь ручьём и вот-вот вырвется пронзаюший душукрик отчаяния <..> [10]; Ukrainian. <...> i мати аж стогне з розпачу.; <...> y голосі інженера звучить майжсе розпач.; Не однієї ночі можна було чути ті крики розпачу в нашій нещасній xami [8].; German. Ich erkenne keine Traurigkeit oder Verzweiflung in Ihrer Stimme.; Dort begrüßen sich Menschen mit einem Schrei der Verzweiflung und verabschieden sich mit Jubel [2].

- gesture and facial expression: English. He raised his hands palms upward in a gesture of despair as his voice thickened with emotion.; < .. > feeling shamed by the look of despair on his face, and worse still as he fought to bring back the blankness to cover it.[1]; Russian. Он разглядывает рисунок с разных сторон, выражение отчаяния на лице <...>; Она широко раскрыла глаза, испуганно отпрянула, и ее лицо исказило отчаяние [10].; Ukrainian. Обличчя його було спотворене від розпачу, $i$ в ї̈ грудях через той розпач солодко грало серце.; $\boldsymbol{H a}$ його обличчі теж був вираз розпачу [8].; German. Und diese Verzweiflung im Gesicht, wenn er den Kratzer einfach nicht finden kann $<\ldots>$; Doch dann erinnerte er sich an das verzweifelte Gesicht von Florence und an ihre Tränen [2].

Expression of the "despair" emotion includes also tears and sobbing, suggesting that this emotion is severe and painful experienced both mentally and physiologically: English. Tears of despair and frustration sprang to her eyes.; Tears flowed, anger thundered, sobbing despair drowned the space we sat in [1].; Russian. Слёзы отчаяния брызнули из глаз.; Он рыдал, преисполненный отчаяния, $и$, раскинув руки, пал на колени [10].; Ukrainian. <...> з очей полилися сльози розпачу, без- 
силля $і$ люті.; Доменіка в розпачі схлипнула й безутішно заридала [8].; German. Tränen der Verzweiflung, weil wir so viele zurück lassen mussten, $<\ldots>$; Trotzdem lass uns nicht in Verzweiflung weinen $<\ldots>$ [2].

The analysis shows that the "despair" emotion is conceptualized as aggressive force, causing dysfunction of the human body; in particular, it is concentrated in heart/soul, throat and chest:

- heart/soul: English. <..> he can resurrect hope in a heart filled with despair.; Why do we allow depression and despair to bring our hearts low?; But his heart sank as despair, <...> flooded him [1].; Russian. Черньй коршун разрывал и клевал ее изнутри, наполняя душу отчаянием и болью.; Сердце сжалось от отчаянья [10].; Ukrainian. <..> художник не знав, щзо товаришеве серце красться від розпачу.; Розпач опанував душею молодої дівчини з речей цичанки. Палив нам душу розпач. I серце розтинав, мов гострий меч [8].; German. Und das Herz sank ihm vor Verzweiflung und Verlassenheit.; Die Verzweiflung, die mir das Herz zerreißt, <...> [2].

- throat: English. A burgeoning sense of despair tightened her throat as she glanced down $<\ldots>$; Something very close to despair tightened Lucien's throat.; Her throat was tight with despair [1].; Russian. Когда не осталось сил, и отчаяние стальной хваткой сжнмает горло, <... >; Наконец я почувствовала, что уже не могу дышиать из-за ветра и сдавившего горло отчаяния, < ..> [10];Ukrainian. Зі сцени ллється потік безглуздих слів, горло стискає розпач <..>; Ошелешені вояки складають зброю, розпач стискає горло, дехто не витримує [8]. German. <..> so hätte mich die Verzweiflung erwürgt.; Meine Kehle zieht sich vor Verzweiflung zusammen [2].

- chest: English. His despair grew deeper in the chest.; $<\ldots>$ and unending despair tightening around my chest.; $<\ldots>$ despair welling up inside him and painfully tightening his chest.; I felt pity and despair squeeze my chest like a pair of burning hands [1].; Russian. И тогда в груди моей родилось отчаяние.; Отчаяние взорвалось в груди невыносимой болью [10].; Ukrainian. Розпач, відчай розривали ї̈ груди, хвилинами з'являвся такий жах, щзо изіпеніло сериее.; Невимовний розпач розпирає груди <..> [8]; German. <..> obwohl Angst und Verzweiflung ihr die Brust zuschnürten.; <..> Tausend Seelen in einer verzweifelten Brust [2].

Conclusion. The analysis of the language corpus material confirms that the "despair" emotion is perceived as a negative. Both hedonic and moral values have an influence on the conceptualization of "despair" in English, Russian, Ukrainian and German. However, hedonic prevails over moral values, as can be seen from the analyzed context. Its axiological component explicates in the following ways: 1) when contrasted with positive emotions/feelings; 2) when intensified by other negative emotions/feelings; 3) when accompanied by adjectives that have negative semantics; 4) when causes physical discomfort and actions that have destructive or negative consequences. Objectification of evaluation of the "despair" emotion is performed due to its association with anthropomorphic and naturomorphic features.

\section{ЛИТЕРАТУРА}

1. British National Corpus: веб-сайт. URL: https://www.english- 7. Вольф Е.М. Функциональная семантика оценки. Москва, corpus.org/bnc/ (дата звернення: 13.05.2020)

2. Deutscher Wortschatz Project: веб-сайт. URL: https://corpus.uni-leipzig.de/de/res?corpusId=deu_newscrawlpublic_2018\&word=Verzweiflung (дата звернення: 13.05.2020)

3. Mikołajczuk A. Problem ocen w analizie wybranych polskich nazw uczuć z klasy semantycznej GNIEWU: Uczucia w języku i tekście. Wrocław, 2000. T.14. S. 117-134

4. Stevenson Ch. L. Facts and values: (Studies in ethical analysis)/ Yale UP. New Haven; L., 1964. 125 p.

5. Wright G.H. von. The varieties of goodness. New York: Humanities Press, 1963. 222 p.

6. Арутюнова Н.Д. Типы языковых значений: Оценка. Событие. Факт. Москва: Наука, 1988. 341 с. $1985.228 \mathrm{c}$.

8. Генеральний регіонально анотований корпус української мови: веб-сайт. URL: http://uacorpus.org/ а (дата звернення: 13.05.2020).

9. Локк Дж. Избранные философские произведения: в 2-х томах. Москва: Соцэкгиз, 1960. Т. 1. 532 с.

10. Национальный корпус русского языка: веб-сайт. URL: http://www.ruscorpus.ru/new/ (дата звернення: 13.05.2020)

11. Ніколаєнко Л.І. Оцінка в мовній концептуалізації емоцій групи «співчуття» (на матеріалі польської, української і російської мов). Мовознавство: Науково-теоретичний журнал. 2016. №3. С. 32-40
1. British National Corpus: web-site. Reach via URL: https://www.english-corpus.org/bnc/

2. Deutscher Wortschatz Project: web-site. Reach via URL: https://corpus.uni-leipzig.de/de/res?corpusId=deu_newscrawlpublic_2018\&word=Verzweiflung

3. Mikołajczuk A. The problem of evaluation in the analysis of selected Polish names of emotions from the semantic class "anger": Emotions in language and text. Wroclaw, 2000. V.14. P. $117-134$

4. Stevenson Ch. L. Facts and values: (Studies in ethical analysis)/ Yale UP. New Haven; L., 1964. 125 p.

5. Wright G.H. von. The varieties of goodness. New York: Humanities Press, 1963. 222 p.

\section{REFERENCES}

6. Arutyunova N.D. Types of Language Meanings: Evaluation. Event. Fact. Moscow: Nauka, 1988. 341 p.

7. Wolf E.M. Functional semantics of evaluation. Moscow, 1985. $228 \mathrm{p}$.

8. General Regionally Annotated Corpus of Ukrainian (GRAC): web-site. Reach via URL: http://uacorpus.org/

9. Locke J. Selected philosophical works: in two volumes. Moscow, 1960. V. $1.532 \mathrm{p}$

10. Russian National Corpusrus: web-site. Reach via URL: http://www.ruscorpus.ru/new/

11. Nikolaenko L.I. Evaluation in language conceptualization of emotions of the "compassion" (in Polish, Ukrainian and Russian). Linguistic: Scientific and theoretical journal. 2016. No. 3. P. $32-40$ 